\title{
POLAND'S MEMBERSHIP IN THE MONETARY UNION IN LIGHT OF SELECTED LEGAL AND INSTITUTIONAL ASPECTS OF THE CRISIS IN THE EURO AREA
}

\section{Tomasz Hoffmann*}

Abstract: The principal research goal of this paper is to indicate and characterise the legal and institutional instruments that have been implemented in order to mitigate the consequences of the crisis. The main cause of the crisis in the euro area was the all too liberal approach to financial speculation coupled with a loss of control over financial markets on the part of the authorities of particular Member States.

The crisis that had initially engulfed the United States spread relatively quickly across Western Europe, affecting the Members States of the EU. The crisis was felt most deeply in countries such as Portugal, Spain, Ireland, Italy, and Greece, whereas the many negative consequences of the excessive debt incurred by these countries affected the entire EU. The hitherto applied fiscal and legal means of counteracting the consequences of the crisis, although appropriate, have failed to yield the anticipated results, leading to mounting political tension between the major contributors amongst EU Member States.

* Tomasz Hoffmann, Koszalin University of Technology, Faculty of Modern Languages and Social Communications 
Key words: UE, financial markets, financial crisis, euro area, EU Member States

\section{Introduction}

The crisis that had initially engulfed the United States spread relatively quickly across Western Europe, affecting the Members States of the EU. Both the individual states and particular European institutions began work on an appropriate strategy to mitigate the consequences of the crisis plaguing the euro area, this most precious of achievements of European integration processes. As time has shown, the steps taken, although relatively consistent, have failed to yield satisfactory results, as far as their effectiveness is concerned.

The crisis was felt most deeply in countries such as Portugal, Spain, Ireland, Italy, and Greece, whereas the many negative consequences of the excessive debt incurred by these countries affected the entire EU. The hitherto applied fiscal and legal means of counteracting the consequences of the crisis, although appropriate, have failed to yield the anticipated results, leading to mounting political tension between the major contributors amongst EU Member States. The principal research goal of this paper is to indicate and characterise the legal and institutional instruments that have been implemented in order to mitigate the consequences of the crisis.

My research hypothesis is as follows: the main cause of the crisis in the euro area was the all too liberal approach to financial speculation coupled with a loss of control over financial markets on the part of the authorities of particular Member States. Insufficient convergence between the states comprising the euro area was a contributing factor. On the other hand, the potential legal and institutional solutions applied have failed to dramatically improve the situation of the monetary union. In the current narrative dynamic, the prevailing view is that there is no full diagnosis and, simultaneously, no prognosis with regard to improving the situation across the entire monetary union. 


\section{Diagnosis of the crisis and the need for change}

The main source of the crisis, both globally and in Europe, was a lack of proper supervision over the financial market. ${ }^{1}$ This statement is based on rather substantial diligence, as - to this date - the doctrine and literature have both failed to investigate the roots of the crisis. Nevertheless, it should be noted that the crisis emerged in the United States, on the mortgage loan market, as early as in 2008 and, for all intents and purposes, spread to EU Member States from there. Some financial policy experts have been frank in their publications, blaming the United States for the crisis in the euro area. ${ }^{2}$

The crisis in the Eurozone is also a product of a structural imbalance in the global economy. This consists in some countries reliably showing a positive balance of payments and increasing their reserves, while others have a negative balance of payments, resulting in growing debt. A certain imbalance can be found not only outside the European Union but also within it, where two groups co-exist - one with a foreign trade surplus ${ }^{3}$ and the other with a current account deficit. ${ }^{4}$

The crisis in the euro area is not just a crisis of legal tender and its function, but also a crisis of public debt. Among the countries that make up the European Union, some incurred considerable debt, quite often as a result of decisions that were chiefly political, rather than economic, in nature. ${ }^{5}$

According to some researchers, the crisis in the euro area is a symptom of the institutional weakness of the European Union and of its faulty economic policy mechanism that is based on a centralised monetary policy and a decentralised fiscal policy pursued by particular EU Member States. ${ }^{6}$

1 G.A. Akerlof, R. Shiller, Animal Spirits: How Human Psychology Drives the Economy, and Why It Matters for Global Capitalism. Princeton University Press, Princeton,2009, at pp. 12-20.

2 J. Kundera, Kryzys w strefie euro. Przyczyny i metody przezwyciężenia [Crisis in the Euro area and methods of its overcoming], [in:] K. Opolski, J. Górski (ed.), 'Perspektywy integracji ekonomicznej i walutowej w gospodarce światowej. Dokąd zmierza strefa euro?' [Perspectives of economic and monetary integration in global economy. Where does the Euro area go from here?], Warsaw 2012, at p. 30.

3 Members of this group include Germany, the Netherlands, Austria, and Belgium.

4 Members of this group include Greece, Portugal, Spain, Ireland, France, and Italy.

5 Examples of such countries include Greece, Italy, Portugal, Spain, and Ireland.

See J. Kundera, Poland in the European Single Market, Wrocław 2010. at pp. 149-192.

6 J. Kundera, op. cit., at p. 31. 
Yet another root of the crisis were the provisions of the Treaty of Maastricht concerning the role of the European Central Bank. Finally, as others argue, the euro has, as it were, become a victim of its own success arising from achieving the position of a global legal tender and a major component of foreign currency reserves. This, in turn, gave rise to specific problems, including the impact it had on various euro area members' exports to third country markets. ${ }^{8} \mathrm{M}$. Pietrzykowski names, among others, the following causes of the crisis in the euro area:

- globalisation of the world economy, leading to significant fluctuations in asset prices on financial markets and initiating a process of accrual of massive imbalances in terms of the balance of payments on commodity markets;

- economic policy errors, leading to the emergence of speculative bubbles on markets;

- rapid development of complex financial instruments, including derivatives, and unlimited trading in such instruments;

- absence of appropriate risk assessment mechanisms combined with unjustified optimism regarding future developments;

- absence of a market regulator. ${ }^{9}$

In the aftermath of the financial crisis, some EU Member States could no longer operate in a normal way. ${ }^{10}$ Therefore, an attempt was made to introduce appropriate reforms, which were to mitigate the consequences of the financial crisis. Initial steps taken by the European Central Bank focused on ensuring liquidity and stabilising the monetary market. ${ }^{11}$ A programme was introduced providing for the purchase of bonds issued from 2011 on and used predominantly by Ireland, Portugal, and Greece. New

7 The main objective of the European System of Central Banks was to maintain stable prices. The European Central Bank was prohibited from granting overdraft facilities or any other loans to EU institutions or bodies, central governments, and regional authorities of Member States. Furthermore, the European Central Bank and national central banks were not to acquire debt securities directly from the aforementioned entities.

8 J. Kundera, op. cit., at p. 32.

9 M. Pietrzykowski, Polska na drodze do reformowanej strefy euro [Poland on its way to the reformed Euro area], Poznań 2014, at pp. 44-50.

10 Greece may serve as an example.

11 The European Central Bank policy assumed increasing the scale of unlimited open market operations, broadening the scope of instruments securing its refinancing operations, preparing an appropriate programme for banks, and effecting specific foreign exchange operations. 
bodies were created: the European Systemic Risk Board and the European Supervisory Authority. The European Systemic Risk Board is an independent EU body, providing macro-prudential oversight over the European financial system..$^{12}$ The European Supervisory Authority exercises an effective and, simultaneously, convergent prudential governance. It also supervises the European banking system. ${ }^{13}$ At the same time, a financial stabilisation mechanism was introduced, providing for the possibility of extending specific financial assistance to a Member State experiencing serious financial troubles. ${ }^{14}$ In December 2012, the European Central Bank launched new instruments in the form of 36-month loans, as part of the Long Term Refinancing Operations. The purpose of the loans was to accommodate the money demand shock. ${ }^{15}$ In 2012, an attempt was made to create a legal framework and supervisory mechanisms for short selling, which was a type of investment strategy consisting in selling securities and other capital market instruments. ${ }^{16}$ In the meantime, the European Union implemented also other initiatives, such as the introduction of the European Economic Recovery Plan, a new system for supervising budgetary and economic policies. ${ }^{17}$ In March 2011, based on recommendations made by a working group led by H. van Rompuy, the European Council adopted a package of six legal acts, colloquially referred to as the six-pack. Their aim was to improve the economic governance in the European Union. ${ }^{18}$ The six-pack comprised the following regulations:

12 See http://www.nbp.pl/home.aspx?f=/systemfinansowy/esrb.html (accessed 7.1.2018); http://ec.europa.eu/economy_finance/articles/governance/2014-08-08review_european_systemic_risk_board_en.htm (accessed 5.5.2016); R.M. Lastra, Central bank independence and financial stability, "Estabilidad Financiera" 2010, no 18.

13 Regulation (EU) No. 1093/2010 of the European Parliament and of the Council of 24 November 2010 establishing a European Supervisory Authority (European Banking Authority), amending Decision No 716/2009/EC and repealing Commission Decision 2009/78/EC, O.J. L 331, 15.12.2010, p. 12-47.

14 EU financial assistance is awarded by a decision of the Council, acting by a qualified majority on a proposal of the European Commission. See Council Regulation (EU) No. 407/2010 of 11 May 2010 establishing a European financial stabilisation mechanism, O.J. L 118, 12.5.2010, p. 1-4.

15 M. Pietrzykowski, op .cit., at p. 90.

16 Regulation (EU) No. 236/2012 of the European Parliament and of the Council of 14 March 2012 on short selling and certain aspects of credit default swaps, Official Journal of the European Union, L 86/1.

17 M. Pietrzykowski, op. cit., at p. 92.

18 M. Pietrzykowski, op. cit., at p. 93. 
- Regulation of the European Parliament on the strengthening of the surveillance of budgetary positions and the surveillance and coordination of economic policies; ${ }^{19}$

- Regulation of the European Parliament on the effective enforcement of budgetary surveillance in the euro area; ${ }^{20}$

- European Parliament legislative resolution on speeding up and clarifying the implementation of the excessive deficit procedure; ${ }^{21}$

- Regulation of the European Parliament on the prevention and correction of macroeconomic imbalances; ${ }^{22}$

- Regulation of the European Parliament on enforcement action to correct excessive macroeconomic imbalances in the euro area; ${ }^{23}$

- Council Directive on requirements for budgetary frameworks of the Member States. ${ }^{24}$

The Regulation of the European Parliament on the strengthening of the surveillance of budgetary positions and the surveillance and coordination of economic policies applies to states covered by the recovery and development part. The European Commission may decide to subject a particular Member State to increased surveillance if it deems the situation of that state a threat to the remaining members of the euro area.

The Regulation of the European Parliament on the effective enforcement of budgetary surveillance in the euro area establishes sanctions with respect to the excessive deficit procedure and macroeconomic

19 Regulation (EU) No. 472/2013 of the European Parliament and of the Council of 21 May 2013 on the strengthening of economic and budgetary surveillance of Member States in the euro area experiencing or threatened with serious difficulties with respect to their financial stability, O.J. L 86, 24.3.2012, p. 1-24 .

20 Regulation (EU) No. 1173/2011 of the European Parliament and of the Council, of 16 November 2011, on the effective enforcement of budgetary surveillance in the euro area, O.J. L 306, 23.11.2011, p. 1-7.

${ }^{21}$ European Parliament legislative resolution of 28 September 2011 on the proposal for a Council regulation amending Regulation (EC) No 1467/97 on speeding up and clarifying the implementation of the excessive deficit procedure (COM/2010/0522 - C70396/2010 - 2010/0276(CNS)),O.J. C 56E, 26.2.2013, p. 144-156 .

22 Regulation (EU) No. 1176/2011 of the European Parliament and of the Council of 16 November 2011 on the prevention and correction of macroeconomic imbalances, O.J. L 306, 23.11.2011, p. 25-32.

23 Regulation (EU) No. 1174/2011 of the European Parliament and of the Council of 16 November 2011 on enforcement measures to correct excessive macroeconomic imbalances in the euro area, O.J. L 306, 23.11.2011, p. 8-11.

${ }^{24}$ M. Pietrzykowski, op. cit., at p. 95. 
balance; it applies only to the Member States that are in the euro area. ${ }^{25}$ The Regulation of the European Parliament on the prevention and correction of macroeconomic imbalances introduced a new coordination procedure in respect of the prevention and correction of macroeconomic imbalances. On the other hand, the Council Directive on requirements for budgetary frameworks of the Member States contained detailed rules concerning the characteristics of the budgetary frameworks of Member States, which were to ensure that the states fulfil their obligations with respect to avoiding excessive government deficit. The deadline for implementing the provisions was set for 31.12.2013. ${ }^{26}$ The introduction of the six legal acts (the so-called six-pack) into the legal and institutional system of the European Union was to strengthen the supervision over economic policies pursued by particular EU Member States. The six-pack was also to ensure the correct functioning of national finances through a multitude of preventive and, simultaneously, remedial actions. ${ }^{27}$

The adoption of the six-pack is considered to be a success of both the Polish and Hungarian presidency, ${ }^{28}$ as the countries actively cooperated in setting the new rules governing the development of the Monetary Union. ${ }^{29}$ Since the so-called six-pack entered into force, there have been voices stating that the adoption of those six legal acts could lead to EU governance being centralised. ${ }^{30}$ However, contrary to the aforementioned pronouncements, the reform proved to be but a small step on the way to full recovery for the euro area. The European Union attempted further reforms to the end of improving its economic policy governance. At the time, the rules of the so-called European Semester entered into force. Its timeline is shown in the table.

25 Ibidem.

26 M. Pietrzykowski, op. cit., at p. 97.

27 See http://www.euractiv.pl/gospodarka/wywiad/szeciopak-zdyscyplinuje-pastwaczonkowskie-ue-002969 ( accessed 5.1.2018).

28 See House of Lords, European Union Committee, Chapter 5. The December 2011 European Council and the Proposals for treaty change, [in:] Twenty-Fifth Report “The euro area crisis", 7.2.2012, http://www.publications.parliament.uk/pa/ld201012/ ldselect/ldeucom/260/26008.htm\#n114 (accessed 7.1. 2018).

29 A. Gostyńska, P. Tokarski, Reforma zarzq̨dzania gospodarczego Unii Europejskiejmałe kroki wobec dużych problemów [The reform of economic governance in the European Union], “PISM Bulletin” 2011, no 94.

30 See http://www.bankier.pl/wiadomosc/Czy-szesciopak-uratuje-strefeeuro-2421045.html (accessed 7.1. 2018). 
Table 1. European Semester Timeline

\begin{tabular}{|c|c|}
\hline Period & Description \\
\hline November n-1 & $\begin{array}{l}\text { Having analysed the economic situation, } \\
\text { the European Commission identifies priorities for } \\
\text { the financial year ahead. As part of a prevention } \\
\text { procedure, the Commission checks whether in } \\
\text { a given year there have been any events that could } \\
\text { lead to macroeconomic imbalance and then issues its } \\
\text { opinions and recommendations. }\end{array}$ \\
\hline December n-1 & $\begin{array}{l}\text { Member States adopt final annual budgets, taking into } \\
\text { account the recommendations made by the European } \\
\text { Commission and their finance ministers' opinions. }\end{array}$ \\
\hline February/March & $\begin{array}{l}\text { The European Parliament together with EU ministers } \\
\text { of labour, economy, finance, and competition } \\
\text { discuss the annual economic growth analysis, } \\
\text { after which the European Commission publishes } \\
\text { a detailed assessment of the situation of particular } \\
\text { countries from the perspective of the presence } \\
\text { of macroeconomic imbalances. }\end{array}$ \\
\hline April & $\begin{array}{l}\text { Member States present stability programmes by } 15 \\
\text { April or convergence programmes by the end of April. }\end{array}$ \\
\hline May & $\begin{array}{l}\text { The European Commission presents its country- } \\
\text { specific recommendations regarding economic policy. }\end{array}$ \\
\hline June/July & $\begin{array}{l}\text { The European Council approves the recommendations, } \\
\text { adopting the final document in July. }\end{array}$ \\
\hline October & $\begin{array}{l}\text { By } 15 \text { October, Member States present the European } \\
\text { Commission with their draft budgets for the year } \\
\text { ahead. If a draft is not compatible with the medium- } \\
\text { term obj0ectives of a given country, the European } \\
\text { Commission may request that the plan be amended. }\end{array}$ \\
\hline
\end{tabular}

Source: M. Pietrzykowski, Polska na drodze do reformowanej strefy euro [Poland on its way to the reformed Euro area], Poznań 2014, at p. 94.

The European Semester is a system of procedures coordinating the economic and budgetary policy of the European Union. The intention behind introducing regulations falling within the scope of the European Semester was to ensure convergence, stability, and adequate economic growth, as well as to create favourable conditions for the implementation 
of the EUROPE 2020 strategy. ${ }^{31}$ Additionally, the European Semester is to monitor the economic situation in EU Member States. A downside of this mechanism is the long cycle of preparation and discussion of the documents it covers. The final conclusions and recommendations are based on data from two years prior. Another downside is the fact that throughout the European Semester multiple Union institutions prepare numerous documents, which in turn affects the free flow of information and precludes the possibility of taking quick steps as part of the European Semester. ${ }^{32}$ As the crisis in the euro area demonstrated, problems in one Member State can spread to other countries. This phenomenon has been referred to as the domino effect.

Consequently, Member States resolved to introduce even stronger mechanisms dedicated to the euro area. Consequently, in November 2011, the European Commission proposed adopting new regulations, which were to strengthen budgetary supervision in the European Union. ${ }^{33}$ The new reform package entered into force on 30 May 2013, across the entire euro area. Its aim was to further strengthen mechanisms related to fiscal policy coordination in the euro area. It comprised the following two legal acts:

- Regulation (EU) No. 472/2013 of the European Parliament and of the Council of 21 May 2013 on the strengthening of economic and budgetary surveillance of Member States in the euro area experiencing or threatened with serious difficulties with respect to their financial stability;34

\footnotetext{
31 Europe 2020: A strategy for smart, sustainable and inclusive growth, European Commission, COM (2010) of 3.3.2010.

32 K. Szczerski, Re-konfiguracja czy re-konstrukcja? Kryzysowe zmiany sensu system politycznego Unii Europejskiej [Reconfiguration or reconstruction? Crisis changes of the European Union's political system sense], [in:] T.G. Grosse (ed.), 'Między polityką a rynkiem. Kryzys Unii Europejskiej w analizie ekonomistów i politologów’ [Between politics and market. The European Union Ciris under analysis of economists and political scientists], Warsaw 2013, at pp. 85-100; F. Scharpf, Unia walutowa, kryzys fiskalny oraz erozja demokracji [Currency union, fiscal crisis, and the erosion of democracy], "Nowa Europa. Przegląd Natoliński” 2013, no 2, at pp. 175-226.

33 See http://europa.eu/rapid/press-release_MEMO-13-457_pl.htm (accessed 7.1.2018).

34 Regulation (EU) No. 472/2013 of the European Parliament and of the Council of 21 May 2013 on the strengthening of economic and budgetary surveillance of Member States in the euro area experiencing or threatened with serious difficulties with respect to their financial stability, O.J. L 140, 27.5.2013, p. 1-10 .
} 
- Regulation (EU) No. 473/2013 of the European Parliament and of the Council of 21 May 2013 on common provisions for monitoring and assessing draft budgetary plans and ensuring the correction of excessive deficit of the Member States in the euro area. ${ }^{35}$

Regulation (EU) No. 472/2013 of the European Parliament and of the Council applies to all Member States in the euro area and provides for detailed governance with respect to countries covered by the corrective part of the Stability and Growth Pact. A Member State subject to enhanced surveillance is obliged to take all the recommendations issued by the European Commission and aimed at improving the condition of the government finances of that Member State into consideration in its actions. Every three months, the Member State submits appropriate reports from the aforementioned actions, which are then reviewed by the European Commission. The surveillance continues until the Member State has repaid at least $75 \%$ of the financial assistance received from one or several other Member States.

Regulation (EU) No. 473/2013 of the European Parliament and of the Council specifies clear and simplified procedures for enhanced surveillance in Member States experiencing significant difficulties with respect to sustaining financial balance, as well as in Member States receiving financial assistance or those about to cease to participate in financial assistance. The two-pack increased the monitoring system and budgetary coordination, thus supplementing the provisions of the European Semester. ${ }^{36}$

Another novelty introduced by the European Union was the Fiscal Compact (known as the Euro Plus Pact), a brainchild of A. Merkel and N. Sarkozy. It was signed by 25 Member States (without the United Kingdom and the Czech Republic). The aim of the pact was to mitigate the consequences of the crisis affecting the entire continent. ${ }^{37}$ The pact forced Member States to apply the so-called "golden principle," which states that the annual budget deficit can never exceed $0.5 \%$ of the GDP. ${ }^{38}$

35 Regulation (EU) No. 473/2013 of the European Parliament and of the Council of 21 May 2013 on common provisions for monitoring and assessing draft budgetary plans and ensuring the correction of excessive deficit of the Member States in the euro area, OJ L 140, 27.5.2013, p. 11-23.

${ }^{36}$ M. Pietrzykowski, op. cit., at p. 100.

37 Greece and Italy in particular.

38 See http://www.pwe.org.pl/ue-przyjela-pakt-fiskalny (accessed 7.1.2018). 
The European Commission intended for the principle to be implemented into national law, which gave rise to fierce controversy. A discussion in this regard flared up in Poland, as well. ${ }^{39}$ Eventually, however, President B. Komorowski found the principle to be harmless enough and ratified the treaty on 24 July $2013 .^{40}$

As a result of the treaty entering into force, Poland will be able to participate in European summits dealing with the issue of competition, as well as in meetings relating to the implementation of the pact. This is significant due to the Europeanisation process, which focusses on transferring an increasing number of decisions from a national level to a supranational level. At present, it is difficult to definitively evaluate the rules under which the fiscal pact operates. An accurate assessment of the pact will only be possible after more than a decade, once the possibility of "circumventing" its provisions through creative accounting or certain simulated solutions has been put to the test. ${ }^{41}$ The subject of a Banking Union was first broached by J.M. Barroso in June 2012. In May 2012, at the European Council, H. van Rompuy proposed a specific concept of such a union. ${ }^{42}$ Its main elements centred around the following four pillars:

- first pillar - integrated financial markets;

- second pillar - integrated budgetary framework;

- third pillar - integrated budgetary policy;

- fourth pillar - provisions for necessary democratic legitimacy. ${ }^{43}$

The Banking Union was to consist of the following elements:

- first element - i.e., a single supervisory mechanism - as part of which the European Central Bank was empowered to exercise supervision over banks in the euro area;

39 See http://www.obserwatorfinansowy.pl/tematyka/makroekonomia/paktfiskalny-nie-dziala (accessed 6.5.2016); http://www.eostroleka.pl/afera-wokol-paktufiskalnego-donald-tusk-zlamal-konstytucje,art28782.html (accessed 6.5.2016); A. Gostyńska, P. Tokarski, Spór o nowy pakt fiskalny. Analiza i ocena [The dispute over the new fiscal pact. Analysis and assessment], "PISM Bulletin" 2012, no 17.

40 M. Pietrzykowski, op. cit., at p. 101.

41 Ibidem.

42 A Roadmap towards a Banking Union (COM/2012/0510) and A blueprint for a deep and genuine economic and monetary union Launching a European Debate (COM/2012/0777).

43 M. Pietrzykowski, op. cit., at p. 102. 
- second element - a single resolution mechanism - to be employed by the Single Resolution Board and national resolution bodies as part of the single mechanism;

- third element - a European deposit insurance scheme. ${ }^{44}$

The Banking Union was to form a part of the EMU and its implementation process was to comprise three stages:

- Stage one was planned for the years 2012-2013. It was assumed that appropriate government finance management and separation between banks and governments could be achieved during that period; $;^{45}$

- Stage two was planned for the years 2013-2014 and was to consist of two elements: the culmination of works on an integrated financial framework in the form of establishing a single body, which was to provide a quick and simple resolution; the creation of a mechanism enabling better coordination, convergence, and effective enforcement of relevant policies;

- Stage three - after 2014 - was to be the turning point for the entire deepening of the EMU. Its main objective was to increase the EMU's resistance to all kinds of economic shocks through appropriate decision making. ${ }^{46}$

Subsequent legislative works resulted in the European Council calling on the European Parliament and the Council of the European Union, on 20-21 March 2015, to adopt an appropriate legal act, which was to specify the rules of operation of the Single Resolution Mechanism. Member States in the euro area were also requested to take appropriate steps in terms of the Single Resolution Mechanism. The mechanism in question became operational as of 1.1.2016. ${ }^{47}$

44 Ibidem.

45 This stage was to consist of five elements, including the conclusion of works on a strengthened fiscal management framework, creation of the TSCG, creation of the CRR/ CRDIV, creation of the EMS, as well as the conclusion of a treaty concerning the resolution of banks and deposit guarantees.

46 J.J. Węc, Proces konstytuowania Unii Bankowej. Geneza, podstawy prawne, cele $i$ zasady dziatania [The making of the banking union. Origins, legal basis, goals and operation rules], "Rocznik integracji europejskiej" 2014, no. 8, at pp. 33-34; K. Dul, Europejska Unia Bankowa - przyczyny, wprowadzenie oraz potencjalne skutki [The European banking union - reasons, introduction, potential consequences], Lublin 2015, at pp. 8-9.

47 See http://przegladpm.blogspot.com/2016/01/jednolity-mechanizmrestrukturyzacji-i.html (accessed 2.1.2018). 
The Banking Union was created to the end of identifying the gaps created in the banking system as a result of the crisis of 2007. Thus, it could be said that the idea to create the Banking Union is a response to the potential problems of the future. Poland, in deciding on its accession to the Banking Union, ought to consider the costs this would entail and weigh them against the benefits for the domestic economy that could result from entering the structures of the Banking Union, which - according to European Commission Vice-President Valdis Dombrovskis - is to be created in 2018. The Banking Union will supplement the economic and monetary union; its goal will be to improve banking supervision with respect to players operating at a European level. ${ }^{48}$ On the other hand, near the end of 2017, Germany put forward a proposal for transforming the European Stability Mechanism into a European Monetary Fund, whose objective will be granting loans aimed at eliminating problems arising from the financial crisis. Granting a loan would be contingent on the Member State passing specific reforms aimed at improving its economic situation. Additionally, the European Monetary Fund is to focus on debt restructuring in the euro area, which could negatively affect private investors. The institution will be of an intergovernmental nature, and it will be subordinated to the main contributors, most notably to Germany, which will undoubtedly furnish them with significant and powerful instruments for determining the future of the euro area. ${ }^{49}$

Poland, aspiring to join the euro area, should monitor the negotiations and political climate in Germany, in particular as regards the future of the euro area. This can provide it with certain clues as to the direction it should adopt. Thus far, the new government's activity in the context of Poland's membership in the Monetary Union has been quite drastically limited. Practically, all the current arrangements follow from the strategy for Poland's integration into the euro area that was adopted during the crisis.

48 See http://biznes.gazetaprawna.pl/artykuly/1078182,ekspert-o-unii-bankowej. html (accessed 2.1.2018).

49 T.G. Grosse, Niemiecka wizja reform w strefie euro [The German vision of the Eurozone reforms], http://cakj.pl/2017/10/12/niemiecka-wizja-reform-w-strefie-euro (accessed 12.1. 2018). 


\section{Strategy for Poland's integration into the Euro area}

The Polish economy, particularly in comparison with peripheral Member States in the euro area, has a rather solid economic foundation. In 2009, when Europe was hit by a wave of crisis, Poland managed to avoid recession. ${ }^{50}$ This shaped the perception of Poland as a reliable country with a competitive economy. A number of factors contributed to this situation, including the floating exchange rate regime, an inflow of financial assistance from European structural funds, high domestic demand, the resourcefulness of Poles, the absence of financial crisis in the country, and savings in the sector of government finance. Therefore, it could be said that Poland dealt with the crisis best out of all the Central and Southern European countries. ${ }^{51}$

The fact that Poland is to become a member of the Economic and Monetary Union was clear already at the stage of its accession negotiations. At the time, no requests for transitional periods were made in respect of the Economic and Monetary Union.

As a result, Poland entered the third stage of the EMU as a country subject to derogation. This means that it is obliged to adopt the euro, as a single currency, in the future. However, in order to join the EMU, Poland has to achieve sustainable nominal and legal convergence. ${ }^{52}$ In the meantime, the Polish authorities prepared a strategy for Poland's integration into the euro $a r e a^{53}$ and appointed a Government Plenipotentiary for Euro Adoption in Poland, whose duties included the following:

- coordinating preparations for adopting the euro;

- issuing guidelines and recommendations;

- notifying the Prime Minister of any threats to and delays in the performance of the Plenipotentiary's duties, as well as proposing remedial actions. ${ }^{54}$

50 Something that practically no other economy in the EU managed to accomplish.

51 M. Pietrzykowski, op. cit., at p. 134.

52 The assessment is made by the European Commission and the European Central Bank, which compile convergence reports and then make an appropriate decision on abrogating the derogation.

53 Strategic Guidelines for the National Euro Changeover Plan, Warsaw 2010.

54 Regulation of the Council of Ministers of 13 January 2009 on establishment of the Government Plenipotentiary for Euro Adoption in Poland, Polish O. J., No. 11, item 60 . 
The Plenipotentiary enjoyed the support of the Bureau of the Government Plenipotentiary for Euro Adoption in Poland, operating within the Ministry of Finance. ${ }^{55}$

Another body created for the purpose of coordinating the process of Poland's assimilation into the structures of the Economic and Monetary Union is the Interinstitutional Organisational Structure for Euro Adoption, established in November 2009. It was tasked, among others, with drafting a National Euro Changeover Plan, as well as with preparing an action plan and presenting it to the Council of Ministers. The following entities are responsible for the process of adopting the euro in Poland: the National Coordination Committee, the Coordinating Council, and numerous advisory bodies. ${ }^{56}$ Another institution shouldering the responsibility for preparing the country for its integration into the euro area is the National Bank of Poland, which - upon Poland's entry into the EMU - will become a part of the Eurosystem. In light of the above, it should be assumed that the accession to the euro area will result in transferring selected competences of the National Bank of Poland to the European Central Bank. This, in turn, will require a constitutional amendment, including altering the wording of Articles 144(3)(25), 198(1), 230(1), and 227(1) of the Constitution

55 See http://www.mf.gov.pl/ministerstwo-finansow/dzialalnosc/integracja-zestrefa-euro/biuropelnomocnika-rzadu-ds-euro (accessed 7.1. 2018).

56 1. Working Committees for Euro Changeover Preparations in the Republic of Poland. Members of the National Coordination Committee include the following: 1) the chairperson - Government Plenipotentiary for Euro Adoption in Poland, hereinafter referred to as the "Government Plenipotentiary"; 2) the co-chairperson - Plenipotentiary of the National Bank of Poland's Management Board for Euro Changeover, hereinafter referred to as the "Plenipotentiary of the National Bank of Poland's Management Board"; 3) members: a) Minister - Member of the Council of Ministers in charge of the work of the Standing Committee of the Council of Ministers, b) Secretary or Undersecretary of State in the Ministry of Administration and Digitalisation, c) Secretary or Undersecretary of State in the Ministry of Economy, d) Secretary of State in the Ministry of Foreign Affairs, e) President of the Office of Competition and Consumer Protection, f) President of the Government Legislation Centre, g) President or Vice-President of the Polish Financial Supervision Authority. 2. At the request of a member of the Committee and subject to the chairperson's consent, other people - including NGO representatives may also participate in the meetings of the Committee. 3 . The following persons are also permitted to attend the meetings of the Committee: 1 ) permanent representatives of members of the Committee, referred to in sec. 1, individually appointed by competent bodies or institutions; 2) Government Plenipotentiary's representative. The Working Committee for Legal Adjustments plays a crucial role. 


\section{Figure 1 Institutional structure of bodies responsible for the strategy for euro adoption in Poland}

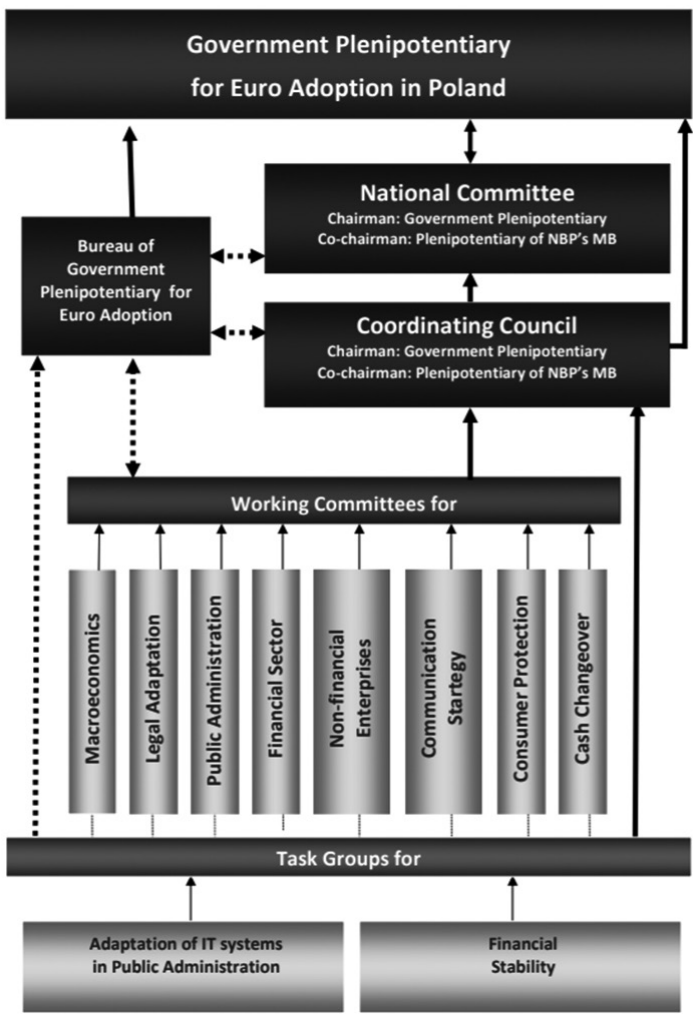

Source: Author's own materials based on http://www.mf.gov.pl/ministerstwo-finansow/dzialalnosc/ integracja-ze-strefa-euro/biuropelnomocnika-rzadu-ds-euro (accessed 7.1.2018); See also J. Dominik, Strategia przygotowań Polski do wprowadzenia euro [The strategy for Poland's preparations to the Euro changeover], Warsaw 2014 (multimedia presentation)

of the Republic of Poland..$^{57}$ Aside from the constitutional amendment, planning for the adoption of a single currency in Poland will have to entail introducing modifications to relevant legal acts of a lower rank. ${ }^{58}$

57 It provides for the exclusive right of the National Bank of Poland to issue money, decide and pursue the monetary policy of the Republic of Poland, as well as for its responsibility for the value of Polish legal tender. This is due to the fact that Poland's full accession to the EMU will entail transferring the competences of the National Bank of Poland in respect of issuing money and determining and pursuing a monetary policy to the ESCB.

58 K. Majchrzak, Prawne aspekty wprowadzenia euro w Polsce [Legal aspects of the Euro introduction in Poland], "Analiza Natolińska" 2013, no 8, at pp. 12. 
In 2010, a rough draft of the National Euro Changeover Plan was prepared, resulting in the creation of a document containing over 1,000 pages of analyses, including an outline of the necessary constitutional amendment. The final version of the National Euro Changeover Plan was drawn up in 2011, providing for a detailed scope of actions and timeline for the introduction of a single currency. Simultaneously, twinning programmes involving Austria, the Netherlands, and Slovakia were executed. In 2013, the Polish National Euro Changeover Plan was updated, so as to take into account the effect that the crisis had on Poland's entry into the euro area and provide further details concerning actions pertaining to particular issues.

Poland's planned accession to the euro area has inspired many political and theoretical discussions. It has been emphasised that euro adoption should occur by way of an expression of direct democracy, namely - in the form of a referendum. Despite the standpoint adopted by politicians, most lawyers challenge the idea of a referendum, claiming that the issue of replacing the Polish złoty with the euro has already been unequivocally decided by the provisions of the Treaty of Accession, whereby Poland undertook to meet the convergence criteria for its accession to the euro area. ${ }^{59}$ After Law and Justice (PiS) came into power in 2015, Prime Minister B. Szydło abolished the position of the Government Plenipotentiary for Euro Adoption.

There appear to be two reasons for such a decision: firstly, PiS is opposed to entering the euro area in the foreseeable future, with most of the governing party's MPs convinced that the Polish złoty is in itself an attribute of sovereignty; secondly, the adoption of a new currency would require amending the Constitution, as well as a number of other legal acts. $\mathrm{PiS}$ is also sceptical of joining the euro area in light of the current crisis. Politicians from the governing party believe that Poland can delay its entry into the Eurozone until the situation in the European Union has changed, including the very structure of the EMU. ${ }^{60}$

$59 \quad$ K. Majchrzak, op. cit., at p. 18.

60 See http://biznes.gazetaprawna.pl/artykuly/908497,euro-w-polsce-nie-bedziepis-likwidacja-pelnomocnika-do-spraw-euro.html (accessed 6.1.2018). 


\section{Benefits of adopting a single currency during an economic crisis}

In 2008, operating a floating exchange rate regime helped the Polish economy avoid recession and support the competitiveness of Polish producers on foreign markets. The development of a global crisis took a much heavier toll on countries in the euro area; however, in hindsight, they have managed to achieve better results in terms of shaping their competitiveness indicators and effective management. Membership in the euro area has a beneficial influence on a number of factors, potentially compensating for the disadvantages of not having one's own currency. ${ }^{61}$

In light of the above, it may be pointed out that accession to the euro area could offer certain advantages, including, among others, an increase in trade intensity, which is seen as a positive factor in terms of its effect on economic growth. Trade - and the development of trade, in particular is conducive to benefitting from specialisation and economies of scale. ${ }^{62}$ This entails a transfer of knowledge and new technologies, which - in the case of Poland - could serve as a catalyst for increased economic growth and improved competitiveness. Entering the euro area should lead to an increase in domestic and international investments. This is due to the fact that the Polish economy is perceived as less attractive than those of EMU members.

Potential investors expect a higher rate of return on investment when they consider investing in Poland than upon investing in countries that have joined the EMU. When calculating the costs of an investment, they include a premium for investment risk. Once Poland has entered into the Eurozone, the amount of such a premium can be expected to fall. Poland's accession to the EMU and adoption of the euro should serve to limit credit costs and positively influence both price transparency and the new rules for doing business. ${ }^{63}$

In joining the euro area, Poland will stand to benefit from participating in a single financial market. Polish business will enjoy better access to foreign

61 M. Pietrzykowski, op. cit., at p. 160.

62 M. Andrzejewska, I. Górczyńska, Szanse i zagrożenia wejścia Polski do strefy euro [Chances and threats related to joining the Eurozone by Poland], Eódź 2015, at p. 31.

63 In the case of businesses, the lower financing cost combined with the anticipated inflow of foreign capital should contribute to capital accumulation and broader investment activity, thus resulting in increased macroeconomic credibility. 
financial markets and an opportunity to participate in the European bond market. Adopting a single currency will eliminate the exchange rate risk and transaction costs, which will improve price comparability ${ }^{64}$

Another factor contributing to the fact that increased competition will favourably influence economic growth is its potential for stimulating the processes of adopting innovation and the dissemination of new technology, affecting the growth of the Polish economy. Membership in the euro area should have a positive effect on Poland's rating, which, in turn, would translate into a better investment climate and lower government debt valuation. It is important for Poland to prepare for membership from a technical perspective. Issues that have to be considered include the possibility of providing for a period when both currencies are used simultaneously, opening banks on 1 January, adjusting the setting of automated teller machines, ensuring that change in stores is given in euro, securing the supply of starter packages beforehand, and carrying out a thorough information campaign, etc. ${ }^{65}$

Setting a date for Poland's entry into the euro area requires a meticulous analysis, so as to select the most optimal time for carrying out this operation. First and foremost, one has to answer the question of the degree to which Poland needs an autonomous monetary policy and a floating foreign exchange rate, enabling it to stay competitive internationally, and for how long. Following the adoption of the euro, accelerated nominal convergence is to be expected, potentially resulting in increased labour costs.

Therefore, it is necessary to build an appropriate mechanism, which would compensate for undesirable consequences and, simultaneously, increase the rate at which businesses adjust to the new conditions, including increased labour costs. This also means the need to achieve a favourable budgetary position, allowing for interventions to be made to the end

64 The existence of the PLN-EUR exchange rate is one of the reasons for the persisting price differences between Poland and countries from the euro area, with the differences remaining immune to the international flow of goods. They follow, among others, from poor price comparability, presence of transaction costs, and exchange rate fluctuations, causing risk-averse foreign investors to delay their entry into the new market, as it does not offer a sufficiently high rate of return on investment. This situation is conducive to the presence of businesses characterised by low management effectiveness and to less than optimal use of the factors of productions.

65 M. Pietrzykowski, op. cit., at p. 161. 
of lowering the costs of doing business, increasing cost competitiveness, and supporting Polish producers on foreign markets. ${ }^{66}$

\section{Conclusion}

According to the most recent poll conducted by the Public Opinion Research Center CBOS in 2016, Poles find the idea of Poland adopting the euro acceptable; however, they express certain fears stemming from the fact that it is difficult to reliably predict what the future involving the adoption of the euro will look like. This has been all but confirmed by the European economic crisis, which took a considerable toll on the euro area and revealed its weaknesses, consequently contributing to the debt crisis experienced by certain Member States.

Despite the existence of certain legal mechanisms, it did not take long for that crisis to spread from the financial sphere to the real economy. This, in turn, worsened the already disastrous situation in the sphere of government finances of some countries. Those countries that proved unable to maintain sufficient competitiveness of their economies and reign in their government finances found themselves in the most difficult situation. Employing new instruments, which were to diametrically change the structure of the euro area, has failed to live up to expectations. The euro area pursued a number of initiatives aimed at improving fiscal discipline and implementing a new economic governance model in the EMU.

The adopted solutions had a positive influence on the functioning of the monetary area and contributed to its increased stability and efficiency. There is no doubt, however, that the situation in the euro area affected Polish society's outlook on the issue of adopting the euro. Where following the accession to the European Union most Poles were enthusiastic about euro adoption, that enthusiasm has faded in line with the progress of the economic crisis.

Opponents and those as yet undecided are threatened by issues that arose in relation to the financial crisis. Moreover, the Polish government formed by $\mathrm{PiS}$ has taken no consistent steps to implement procedures related to adopting the euro. Official statements made by members of PiS

Ibidem. 
suggest that Poland should enter the euro area on the same terms and conditions as other Member States. ${ }^{67}$

All these aspects have led to a marked decline in society's interest in entering the euro area. Many believe that the adoption of the euro will bring about radical changes in the country, possibly adversely affecting the position of these social groups in society, as well as endangering the existence of a stable and autonomous monetary policy.

Furthermore, both those undecided and opponents of adopting the euro in Poland use the disastrous consequences of the economic crisis in Greece, Portugal, Italy, and Ireland as an argument against Poland's membership in the EMU. It is their belief that joining the euro area will entail inheriting the problems plaguing the euro area as a result of the crisis. Theses advanced by these social groups do not allow one to reliably determine whether the introduction of a single currency would improve or worsen the circumstances of particular social groups.

The situation is further complicated by reports compiled by experts, stating that membership in the euro area will prove advantageous, yet failing to supply any specific arguments in support of this claim. ${ }^{68}$ Despite aforementioned doubts, assuming that the monetary union continues to exist, a single currency in the form of the euro can appeal to society on account of its prospective long-term benefits, as exemplified by the many advantages indicated by respondents. A strong and effective euro is in Poland's best interest, and - upon its accession to the European Union Poland declared that following the derogation period the country would enter the euro area and adopt the single currency.

In this way, the hypothesis that adopting the euro in Poland is a requirement arising out of the provisions of the Treaty of Accession and thus, in some sense, a legal necessity, is validated. From the perspective of economics, one would do well to refer to the experience of other countries that entered the euro area and compare it to selected economic theories concerning monetary issues. Euro adoption will involve legal, political, and social changes, necessitated, as it were, by membership in the euro area.

It is true that the experience of the economic crisis unequivocally suggests that it would be better for Poland to stay out of the euro area and operate a floating exchange rate regime. On the other hand, remaining

67 Such as Germany or France.

68 Professor Rosati's report lists the benefits but fails to provide specific arguments, making a number of assumptions that can neither be validated nor disproved. 
outside the EMU may entail high economic and political costs. In this situation, one cannot escape the conclusion that Poland is, as it were, doomed to become a full member of the euro area, which - in the long run and considering the underlying assumptions of the EMU structure - will be to the country's advantage.

\section{Bibliography}

1. Akerlof G.A., Shiller R., Animal Spirits: How Human Psychology Drives the Economy, and Why It Matters for Global Capitalism, Princeton University Press, Princeton 2009.

2. Andrzejewska M., Górczyńska I., Szanse i zagrożenia wejścia Polski do strefy euro, Łódź 2015.

3. Dul K., Europejska Unia Bankowa - przyczyny, wprowadzenie oraz potencjalne skutki, Lublin 2015

4. Gostyńska A., Tokarski P., Reforma zarzq̨dzania gospodarczego Unii Europejskiej-małe kroki wobec dużych problemów, "PISM Bulletin" 2011, no 94

5. Gostyńska A., Tokarski P., Spór o nowy pakt fiskalny. Analiza i ocena, "PISM Bulletin" 2012, no. 17

6. Grosse T.G., Niemiecka wizja reform w strefie euro, http://cakj.pl/2017/10/12/ niemiecka-wizja-reform-w-strefie-euro.

7. $\quad$ Kundera J., Kryzys w strefie euro. Przyczyny i metody przezwyciężenia, [in:] Opolski K., Górski J. (ed.), 'Perspektywy integracji ekonomicznej i walutowej w gospodarce światowej. Dokąd zmierza strefa euro?', Warsaw 2012.

8. Kundera J., Poland in the European Single Market, Wroclaw 2010.

9. Lastra R.M., Central bank independence and financial stability, "Estabilidad Financiera" 2010, no 18.

10. Pietrzykowski M., Polska na drodze do reformowanej strefy euro, Poznań 2014.

11. Scharpf F., Unia walutowa, kryzys fiskalny oraz erozja demokracji, "Nowa Europa. Przegląd Natoliński” 2013, no 2.

12. Szczerski K., Re-konfiguracja czy re-konstrukcja? Kryzysowe zmiany sensu system politycznego Unii Europejskiej, [in:] T.G. Grosse (ed.), 'Między polityką a rynkiem. Kryzys Unii Europejskiej w analizie ekonomistów i politologów', Warsaw 2013.

13. Węc J.J., Proces konstytuowania Unii Bankowej. Geneza, podstawy prawne, cele i zasady działania, "Rocznik integracji europejskiej” 2014, no. 8. 